\title{
EDITORIAL
}

\section{Stem cells and regenerative medicine}

\author{
Mahendra Rao* \\ See related articles by Donnelly et al., http://stemcellres.com/content/3/4/24, Gupta et al., http://stemcellres.com/content/3/4/25 \\ and Bartel et al., http://stemcellres.com/content/3/4/26
}

\begin{abstract}
The remarkable speed with which the field of stem cell biology has evolved is unprecedented and has already changed the way we do science. In this series of articles we have invited leading experts to present their efforts in moving from the bench to the bedside, with the hope that we can learn from the experiences of the pioneers.
\end{abstract}

\section{Progress whether one likes it or not}

The ability to make embryonic stem cells from human cells allowed us to examine early developmental events and study human disease with human models. In the short span of a decade, over 150 lines are now available in the embryonic stem cell registry maintained by the US government [1].

The remarkable discovery that an embryonic stem celllike state can be induced in virtually every adult cell type changed the way we consider doing experiments. Ever since the remarkable discovery of induced pluripotent stem cells by Takahashi and Yamanaka [2], the field has continued to evolve - with exciting discoveries furthering our understanding of early development, the process of cellular reprogramming, acquisition and maintenance of pluripotency, the determination of cell fate, and enhancing our ability to model diseases in vitro [3]. These advances coupled with parallel advances in gene engineering and gene targeting have allowed for an unprecedented ability to manipulate, perturb and thereby understand human development $[4,5]$.

The remarkable pace of development is reflected in the speed with which discoveries are moving from the bench to the bedside [6,7]. In just about a decade, two companies have obtained US Food and Drug Administration approval to conduct cell-based trials with human

\footnotetext{
*Correspondence: Mahendra.rao@nih.gov

Center for Regenerative Medicine, National Institutes of Health, 50 South Drive Suite 1140, Bethesda, MD 20892, USA
}

embryonic stem cell-derived cells, and a much larger number of trials have commenced with adult stem cells. Screening with primary cells derived from embryonic stem cells or induced pluripotent stem cells has begun, and several groups have described the generation of disease-specific or rescued lines and have shown that panels of lines can be generated [8].

We felt it was important to provide a common forum where such translational studies could be discussed in a single place. Stem Cell Research and Therapy therefore invited a series of articles that highlight the rapid pace of advance and illustrate the breadth and range of the efforts that are in progress.

In the present issue you will see three articles that showcase work being performed using stem cells as cellbased therapy. Gupta and colleagues describe the use of mesenchymal stem cells for cartilage repair [9], while Donnelly and colleagues describe their experience using human neural stem cells to treat spinal cord injury [10]. In the same issue, Bartel and colleagues describe their efforts to manufacture an autologous differentiated cell product for the treatment of critical limb ischemia [11].

We expect to continue this series over the coming months and will continue to showcase both the progress in and the challenges of reducing discoveries to practice and the innovative solutions that investigators have developed. Indeed, many challenges remain. These include issues related to cell manufacture, consent to obtain samples, and the difficulty in designing an appropriate business model to ensure that positive results become widely available and freely accessible.

I encourage our readers to send their comments and to participate in an active discussion and share the results in this forum. I hope these latest review and original research articles will stimulate further thoughts and provide novel solutions for the problems being encountered.

This article is part of a thematic series on Clinical applications of stem cells edited by Mahendra Rao. Other articles in the series can be found online at http://stemcellres.com/series/clinical 


\section{Competing interests}

The author declares that he has no competing interests.

\section{Published: 9 July 2012}

\section{References}

1. NIH Embryonic Stem Cell Registry [http://stemcells.nih.gov/research/ registry/]

2. Takahashi K, Yamanaka S: Induction of pluripotent stem cells from mouse embryonic and adult fibroblast cultures by defined factors. Cell 2006 , 126:663-676.

3. Eisenstein M: IPSCs: one cell to rule them all? Nat Methods 2010, 7:81-85. doi:10.1038/nmeth0110-81

4. Capecchi MR: Gene targeting in mice: functional analysis of the mammalian genome for the twenty-first century. Nat Rev Genet 2005, 6:507-512. doi:10.1038/nrg1619

5. Porteus MH, Carroll D: Gene targeting using zinc finger nucleases. Nat Biotechnol 2005, 23:967-973. doi:10.1038/nbt1125

6. Carpenter MK, Frey-Vasconcells J, Rao MS: Developing safe therapies from human pluripotent stem cells. Nat Biotechno/ 2009, 27:606-613. doi:10.1038/ nbt0709-606

7. Rao MS: Funding translational work in cell-based therapy. Cell Stem Cell 2011, 9:7-10. doi:10.1016/j.stem.2011.06.009

8. Ebert AD, Liang P, Wu JC: Induced pluripotent stem cells as a disease modeling and drug screening platform. J Cardiovasc Pharmaco/ 2012. [Epub ahead of print]

9. Gupta PK, Das AK, Anoop CH, Majumdar AS: Mesenchymal stem cells for cartilage repair in osteoarthritis. Stem Cell Res Ther 2012, 3:25.

10. Donnelly EM, Lamanna JJ, Boulis NM: Stem cell therapy for the spinal cord. Stem Cell Res Ther 2012, 3:24

11. Bartel R, Cramer C, Ledford K, Longcore A, Parrish C, Stern T, Watling S, Zeigler F: The Aastrom experience. Stem Cell Res Ther 2012, 3:26.

doi:10.1186/scrt118

Cite this article as: Rao M: Stem cells and regenerative medicine. Stem Cell Research \& Therapy 2012, 3:27. 